\title{
Literární text ve výuce cizího jazyka - tvorba a ověřování didaktického modelu
}

\author{
Literature in the foreign language classroom - creation and verification \\ of a didactic model \\ Eva Skopečková
}

\begin{abstract}
Abstrakt: Příspěvek představí hlavní výstupy, ale také nové otázky spojené s výzkumem realizovaným na PedF UK v Praze, jehož cílem bylo vytvoření a postupné ověřování didaktického modelu pro adekvátní metodické zpracování a začlenění anglicky psané literatury v intencích RVP G/ZV do výuky AJ v souladu se specifickými aspekty didaktiky anglicky psané literatury. Výsledkem výzkumu bylo vytvoření a následné ověření výše uvedeného didaktického modelu. Výzkum však také otevřel nové otázky spojené právě $\mathrm{s}$ ověřováním tohoto modelu a to zejména v konkrétní školní praxi.
\end{abstract}

Klíčová slova: akční výzkum, anglicky psaná literatura, kurikulární reforma, specifičnost literatury

\begin{abstract}
The paper presents the main results as well as some of the new questions relating a research that was carried out at the Faculty of Education Charles University in Prague. The objective of this research was the creation and gradual verification of a didactic model for the optimal use of English literature in the EFL classroom in compliance with the new curricular documents as well as the specific features of literature. The result of this research was the creation and verification of the above mentioned model. However, the research raised several new questions resulting from the very process of its verification concerning particularly the actual school environment.
\end{abstract}

Keywords: action research, English literature, curricular reform, the specific features of literature

Problematika využívání literatury ve výuce CJ s sebou přináší řadu úskalí a je ovlivňována několika zásadními rovinami, které se této oblasti dotýkají a navzájem se prolínají. Jedná se zejména o rovinu lingvodidaktickou (napřs. aspekt získávání komunikativní kompetence a rozvoje řečových dovedností), ale i o literárněvědné obory (např. aspekt úlohy literatury ve vzdělávání a zejména pak problematika recepce literatury s důrazem na specifičnost práce s literaturou - tj. objasnění základních principů recepční estetiky a její aplikace na literární text jakožto zvoleného literárněvědného směru respektujícího onu specifičnost práce $\mathrm{s}$ literaturou) to vše v souladu se současným pojetím vzdělávání a kurikula (tj. kurikulární reforma a její dopady na výuku anglického jazyka $s$ ohledem na zapojení cizojazyčné literatury). Tyto tři základní roviny představují hlavní teoretická východiska výzkumu realizovaného na PedF UK v letech 2007 až 2009 v rámci modelového semináře s názvem Didaktika anglicky psané literatury pro studenty Učitelství pro SŠ a 2. stupeň ZŠ.Výsledkem tohoto výzkumu bylo vytvoření a následné ověření didaktického modelu pro adekvátní metodické zpracování a začlenění anglicky psané literatury do výuky AJ v souladu s novými kurikulárními dokumenty i specifickými aspekty literatury. Tento výzkum však také otevřel 
nové otázky spojené především s ověřováním a aplikací výše uvedeného modelu ve vzdělávací praxi.

Výše uvedený výzkum si za cíl kladl vytvoření a následné ověření výše popsaného didaktického modelu. S ohledem na cíl celého výzkumu byl jako vhodný výzkumný nástroj zvolen akční výzkum jakožto druh empirického výzkumu, ,jehož cílem je bezprostředně reagovat na nějaký dílčí problém edukační praxe“ (Průcha, 2000). V první fázi výzkumu jsme nejprve $\mathrm{v}$ souladu $\mathrm{s}$ výše uvedenými teoretickými východisky a zároveň $\mathrm{v}$ návaznosti na intence nových kurikulárních dokumentů pro daný stupeň škol vytvořili a popsali model semináře, který byl zaměřen na ověřování nových metodických postupů pro práci s anglicky psanou literaturou vzhledem k výše uvedeným aspektům, tedy na ověřování vlastního didaktického modelu.

Tento didaktický model $\mathrm{v}$ sobě spojuje literárněvědnou rovinu poskytující konkrétní teoretická východiska pro práci s literaturou (tj. principy recepční estetiky Wolfganga Isera) a zároveň rovinu lingvodidaktickou směřuící k získávání komunikativní kompetence $\mathrm{v}$ daném jazyce a současně navazuje na nové kurikulární dokumenty. Nejedná se tedy o nějaký soubor izolovaných technik, které by svého uživatele mohly při práci s konkrétním literárním textem vždy dovést $\mathrm{k}$ jednomu jedinému a vždy totožnému řešení, ale spíše o určitý návod, didaktický model spočívající ve vhodném zapojení principů recepční estetiky, propojení a vhodné kombinaci různých postupů pro práci s cizojazyčným textem, ovšem nyní pro práci s literárním textem, který má své specifické aspekty.

Ve druhé fázi jsme se zaměřili na ověřování tohoto modelu semináře. Model semináře byl ověřován nejprve $\mathrm{v}$ akademickém roce 2007/2008 formou pilotáže a v následujícím akademickém roce pak proběhl vlastní výzkum. Respondenty byli studenti 5. ročníku oboru Učitelství pro SŠ a 2. stupeň ZŠ (celkem 32 respondentů). V rámci vlastního výzkumu byli respondenty studenti 4. a 5. ročníku stejného oboru (celkem 29 respondentů). Pro sběr a pozdější analýzu dat byly využity následující metody: dotazník, obsahová analýza, sylabus semináře, pedagogický deník a pozorování.

Metoda dotazníku byla využita použita pro zjišstování zkušeností a názorů studentů týkajících se používání literatury v cizím jazyce ve výuce angličtiny, ale také na reflexi výše zmíněného modelu semináře. Metoda obsahové analýzy byla již v rámci teoretického výzkumu aplikována na nové kurikulární dokumenty a následně také při porovnávání nových a původních učebních dokumentů s ohledem na zapojení literatury do výuky CJ. Metoda obsahové analýzy pak byla $\mathrm{v}$ rámci vlastního výzkumu aplikována na seminární práce studentů navštěvujících semináŕ, kde jsme sledovali jsme schopnost studentů používat nové metodické postupy pro práci s anglicky psanou literaturou ve výuce AJ. Důležitým zdrojem dat byl také sylabus semináře rozpracovaný do jednotlivých týdnů (tj. tematické okruhy, forma semináře). Dalším významným nástrojem byl pedagogický deník, do kterého byla zaznamenávána vlastní učitelova činnost, ale také učitelovy postřehy a komentáře $\mathrm{k}$ jednotlivým hodinám, práci studentů, apod. Dále bylo v rámci vlastního výzkumu využito také pozorování. (tj. pozorování strukturované, kdy jsme pozorovanou realitu strukturovali do předem prripravených kategorií). Toto pozorování bylo aplikováno $\mathrm{v}$ rámci modelu semináře (tj. při studentských prezentacích) a pomáhalo sledovat, do jaké míry si studenti byli schopni postupně osvojit dané metodické postupy pro práci s cizojazyčnou literaturou.

Celý výzkum byl pak zakončen doplňujícím šetřením na gymnáziích navazující na vlastní výzkum. Konkrétně byli v tomto šetření osloveni učitelé anglického jazyka (celkem šest respondentů) působící na pilotních gymnáziích (tj. gymnázií ověřujících v rámci projektu Pilot G/GP tvorbu ŠVP podle nových kurikulárních dokumentů). Do tohoto šetření se zapojili učitelé AJ ze dvou z šestnácti pilotních gymnázií (tj. Gymnázium Jana Keplera v Praze 6 a 
Gymnázium Oty Pavla v Praze 5). Cílem tohoto doplňujícího šetření byla reflexe modelu semináře s ohledem na RVP G/ZV. Respondenti se vyjadřovali k reálným možnostem využití anglicky psané literatury ve výuce AJ s ohledem na RVP G/ZV, svým vlastním zkušenostem $\mathrm{s}$ prací s cizojazyčnou literaturou ve výuce, ale i jednotlivým tématům modelu semináře a tedy i novým metodickým postupům pro práci $\mathrm{s}$ anglicky psanou literaturou ve výuce $\mathrm{AJ}$ probíraným $\mathrm{v}$ rámci semináře. $\mathrm{V}$ rámci doplňujícího šetření byla pro sběr dat použita metoda polostrukturovaného rozhovoru.

Na základě výstupů výzkumu a dat získaných v průběhu jednotlivých fází výzkumu lze konstatovat, že výše uvedený didaktický model vycházející z principů recepční estetiky Wolfganga Isera je vyváženou kombinací těchto složek, který nejenže plní intence RVP G/ZV, ale zároveň respektuje specifické aspekty anglicky psané literatury jakožto mnohovýznamového fenoménu a současně literatury v cizím jazyce ve výuce AJ. Výsledky výzkumu také prokázaly, že studenti Pedagogické fakulty UK Učitelství pro SŠ a 2. stupeň ZŠ jsou po absolvování specializovaného semináŕe schopni tento didaktický model aplikovat a jsou tedy schopni anglicky psanou literaturu adekvátně metodicky zpracovat a začlenit do výuky v intencích RVP G/ZV a také v souladu se specifickými aspekty didaktiky anglicky psané literatury. Výše uvedený cíl výzkumu byl tedy splněn. Na druhou stranu však nelze tento didaktický model považovat za nějaký jednou pro vždy daný a zcela rigidní sled izolovaných technik nebo instrukcí, který má být jako určitý „,vzorec“ přikládán na jakýkoli literární text s očekáváním podobného či naprosto shodného výsledku u různých čtenárù. Právě s ohledem na fakt, že při práci s literaturou vstupujeme do oblasti, kde „důležité není ani tak poznání jako spíše poznávání, jeho nekonečnost, korespondující s nekonečnou pestrostí a mnohotvárností světa, jehož model literatura představuje“ (Nezkusil, 2004) je nutné také tento didaktický model - a tedy i jednotlivé metodické postupy pro práci s cizojazyčnou literaturou ve výuce CJ tvořící jeho podstatu - chápat jako určitý návod či souhrn zásadních aspektů dané problematiky, které je potřeba respektovat a být $\mathrm{s}$ nimi při práci s literárním textem ve výuce CJ obeznámen. Tento model pak obdobně jako recepce literárního textu může při respektování výše uvedených zásadních aspektů pro práci s literárním textem ve výuce CJ nabývat různých forem, může být upravován a proměňovat se s ohledem na konkrétního čtenáře a literární text, se kterým právě pracujeme, či s ohledem na dané podmínky výuky cizích jazyků.

Výsledky výzkumu tedy potvrdili, že námi navrhovaný didaktický model je skutečně funkčním propojením výše uvedených teoretických východisek a studenti jsou schopni si jej osvojit a aplikovat na literární text. Výzkum však také otevřel nové otázky a nastínil směr dalšího výzkumu, který bude v ověřování daného didaktického modelu dále pokračovat.

Z výsledků výzkumu mimo jiné jasně vyplývá potřeba většího propojení univerzitní přípravy s praxí, respektive propojení modelového semináře a možnosti ověření didaktického modelu ve vzdělávací praxi. V rámci původního výzkumu měl být didaktický model ověrován na samotných absolventech semináře, kdy měli být jednotliví studenti pozorováni při výuce anglického jazyka na gymnáziích a následně s nimi měl být veden rozhovor týkající se nových metodických postupů pro práci s anglicky psanou literaturou a možnostmi jejich využití v praxi. Bohužel množství studentů, kteří po absolvování modelu semináře skutečně působili na gymnáziích jako učitelé anglického jazyka, bylo natolik zanedbatelné, že byli v rámci doplňujícího šetření na gymnáziích osloveni učitelé anglického jazyka, kteří na gymnáziích již pracují, a tedy nikoli absolventi modelu semináře. Výpovědi těchto učitelů tak byly s ohledem na téma výzkumu také zcela relevantní, avšak chyběla zde zpětná vazba samotných absolventů semináře na reálnou školní situaci (tj. chyběla možnost aplikovat dané metody na literární texty ve vzdělávací praxi - v reálném školním prostředí, s reálnými žáky). $\mathrm{V}$ rámci nového výzkumu pokračujícího $\mathrm{v}$ ověřování didaktického modelu pro práci $\mathrm{s}$ cizojazyčnou literaturou ve výuce cizího jazyka by tedy mělo dojít k užšímu propojení 
těchto dvou oblastí, tedy teoretické univerzitní př́ípravy (tj. model semináře) a „reálné“ vzdělávací praxe (tj. otevrrít studentům navštěvující tento seminář možnost aplikace daných metodických postupů ve reálné výuce). Cílem tohoto výzkumu tedy bude další ověřování didaktického modelu pro adekvátní metodické zpracování a začlenění anglicky psané literatury do výuky AJ v souladu s novými kurikulárními dokumenty i specifickými aspekty literatury, ovšem nyní s ohledem na větší provázanost s vzdělávací praxí.

$\mathrm{V}$ souladu s tímto záměrem a v návaznosti na předchozí výzkum bude tedy nejprve $\mathrm{v}$ první fázi výzkumu původní model semináře upraven v souladu s novým výzkumným záměrem tj. v rámci semináře bude studentům otevřena možnost aplikovat dané metodické postupy v reálné výuce (dřívější prezentace studentů, které probíhaly skupinově v rámci semináře, budou po domluvě s konkrétními vyučujícími převedeny do reálné výuky). Ve druhé fázi výzkumu se opět zaměříme na ověřování modelu semináře (tedy samotného didaktického modelu). Model semináře budeme ověřovat nejprve formou pilotáže a následně $v$ rámci vlastního výzkumu, tedy výzkumu reflexe didaktického modelu studenty Učitelství pro SŠ a 2. stupeň ZŠ. Model semináře bude probíhat jakožto povinný seminář pro studenty 5. ročníku oboru Učitelství pro SŠ a 2. stupeň Z ̌̌s.

Také pro tento výzkum se jako nejvhodnější výzkumný nástroj jeví akční výzkum (konkrétně výzkum pro-aktivním). Na základě akčního plánu pak budou pro získání a pozdější analýzu dat, v návaznosti na předchozí výzkum, opět použity zejména metoda dotazníku, obsahové analýzy a pozorování.

Cílem našeho výzkumu bude tedy následné ověřování didaktického modelu pro adekvátního metodické zpracování a začlenění cizojazyčné literatury do výuky cizího jazyka v podmínkách reálné výuky. Konkrétně se budeme snažit o větší propojení teoretické př́ipravy (tj. výše uvedený model semináře) studentů oboru Učitelství pro SŠ a 2. stupeň ZŠ, tedy budoucích učitelů anglického jazyka, a vlastní vzdělávací praxe a pokusíme se námi navrhovaný didaktický model ověřvat - byt' $\mathrm{v}$ omezeném podobě limitované prostorem pro studentské prezentace - v rámci reálné výuky.

\section{Literatura}

Janík, T. (2004). Akční výzkum jako cesta ke zkvalitňování pedagogické praxe. In J. Maňák \& V. Švec (Eds.), Cesty pedagogického výzkumu (pp. 51-67). Brno: Paido.

Nezkusil, V. (2004). Nástin didaktiky literární výchovy (čtyřletá gymnázia a třídy víceletých gymnázií). Z praxe pro praxi. Praha: Pedf UK.

Nezvalová, D. (2003). Akční výzkum ve škole. Pedagogika, 53(3), 300-308.

Průcha, J. (2000). Přehled pedagogiky. Úvod do studia oboru. Praha: Portál.

Rámcový vzdělávací program pro gymnázia. Praha: VÚP v Praze, 2007.

Rámcový vzdělávací program pro základni vzdělávání. Praha: VúP v Praze, 2007.

Skopečková, E. (2010). Literární text ve výuce anglického jazyka. Specifické aspekty didaktiky anglicky psané literatury ve výuce anglického jazyka v kontextu současných proměn české vzdělávací soustavy. Plzeň: ZČU v Plzni.

Zima, P. V. (1998). Literární estetika. Olomouc: Votobia.

\section{Kontakt}

PhDr. Eva Skopečková, Ph.D.

Západočeská univerzita v Plzni

Filozofická fakulta, Katedra anglického jazyka

Sedláčkova 15, 30614 Plzeň

e-mail: skopecko@kaj.zcu.cz 


\section{Bibliografické údaje}

Skopečková, E. (2011). Literární text ve výuce cizího jazyka - tvorba a ověřování didaktického modelu. In T. Janík, P. Knecht, \& S. Šebestová (Eds.), Smíšený design v pedagogickém výzkumu: Sbornik př́spěvků z 19. výročni konference České asociace pedagogického výzkumu (s. 456-460). Brno: Masarykova univerzita.

Dostupné z: http://www.ped.muni.cz/capv2011/sbornikprispevku/skopeckova.pdf doi: 10.5817/PdF.P210-CAPV-2012-59 